\title{
Limnohabitans curvus gen. nov., sp. nov., a planktonic bacterium isolated from a freshwater lake
}

\author{
Correspondence \\ Martin W. Hahn \\ martin.hahn@oeaw.ac.at
}

\author{
Martin W. Hahn, ${ }^{1}$ Vojtěch Kasalický, ${ }^{2}$ Jan Jezbera, ${ }^{1,2}$ Ulrike Brandt, ${ }^{1}$ \\ Jitka Jezberová ${ }^{1,2}$ and Karel Šimek ${ }^{2}$ \\ ${ }^{1}$ Institute for Limnology, Austrian Academy of Sciences, Mondseestrasse 9, A-5310 Mondsee, \\ Austria \\ ${ }^{2}$ Biology Centre of the Academy of Sciences ČR, v.v.i., Institute of Hydrobiology, Na Sádkách 7, \\ 37005 České Budějovice, Czech Republic
}

\begin{abstract}
A chemo-organotrophic, aerobic, facultatively anaerobic, non-motile strain, $\mathrm{MWH}^{-\mathrm{C}} 5^{\top}$, isolated from the water column of the oligomesotrophic Lake Mondsee (Austria), was characterized phenotypically, phylogenetically and chemotaxonomically. The predominant fatty acids of the strain were $\mathrm{C}_{16: 1} \omega 7 c / \omega 6 c, \mathrm{C}_{16: 0}, \mathrm{C}_{12: 1}$ and $\mathrm{C}_{8: 0}-3 \mathrm{OH}$, the major quinone was ubiquinone $\mathrm{Q}-8$ and the $\mathrm{G}+\mathrm{C}$ content of the DNA of the strain was 55.5 mol\%. 16S rRNA gene similarity to the closest related type strains was $96.6 \%$ (Curvibacter delicatus LMG $4328^{\top}$ ) and $95.7 \%$ (Rhodoferax fermentans $\mathrm{FR}^{\top}$ ). Phylogenetic analysis of $16 \mathrm{~S}$ rRNA gene sequences revealed the affiliation of the strain with the family Comamonadaceae (Betaproteobacteria); however, the phylogenetic position of the strain did not support an affiliation to any previously described genus within this family. A family-wide comparison of traits revealed that the strain possesses a unique combination of DNA G $+C$ content, major fatty acids and major 3-hydroxy fatty acid. Furthermore, the strain differs in several traits from the closest related genera. Based on the phylogeny of the strain and differences from closely related genera, we propose to establish the new genus and species Limnohabitans curvus gen. nov., sp. nov. to accommodate this strain. The type strain of Limnohabitans curvus is MWH-C5 ${ }^{\top}\left(=\mathrm{DSM} 21645^{\top}=\mathrm{CCUG} 56720^{\top}\right)$. The type strain is closely related to a large number of uncultured bacteria detected by cultivation-independent methods in various freshwater systems.
\end{abstract}

The bacterioplankton of freshwater habitats is composed mainly of phylogenetic groups absent from marine bacterioplankton and terrestrial habitats (Hahn, 2006; Zwart et al., 2002). Investigations with cultivationindependent methods have demonstrated that the majority of taxa dwelling in the water column of freshwater lakes and ponds represent uncultured and undescribed taxa (Crump et al., 1999; Eiler \& Bertilsson, 2004; Zwart et al., 2002). In this paper, we characterize a strain isolated from the pelagic zone of a freshwater lake that is closely related to uncultured bacteria numerously detected in freshwater samples and propose to establish a new genus and species within the family Comamonadaceae (Betaproteobacteria) to accommodate this strain.

The GenBank/EMBL/DDBJ accession number for the 16S rRNA gene

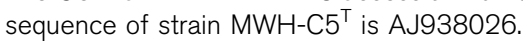

An extended neighbour-joining tree including 16S rRNA gene sequences from uncultured clones, detailed 16S rRNA gene sequence similarity data and a family-wide comparison of phenotypic traits are available as supplementary material with the online version of this paper.
Strain MWH-C5 ${ }^{\mathrm{T}}$ was isolated from deep, oligomesotrophic Lake Mondsee ( $\left.47^{\circ} 50^{\prime} 2.92^{\prime \prime} \mathrm{N} 13^{\circ} 22^{\prime} 25.98^{\prime \prime} \mathrm{E}\right)$ located in Austria. The strain was obtained by using the dilution-acclimatization method (DAM) and nutrient broth soytone yeast extract (NSY) medium (Hahn et al., $2004,2005)$. The isolated bacterium grows on a variety of solidified complex media, e.g. Luria-Bertani agar (Difco $\mathrm{BD}$ ), casitone agar (Difco BD), R2A agar (Remel) and NSY agar (Hahn et al., 2004), forming unpigmented, smooth, convex colonies.

Tests of growth of the strain on single carbon sources resulted only in weak growth. In order to avoid falsenegative results in such tests caused by a too-weak growth response on single substrates, tests of substrate utilization were performed in the presence of complex substrate mixtures as described previously (Hahn et al., 2009). Briefly, growth enabled by utilization of specific substrates was determined by comparison of the $\mathrm{OD}_{575}$ established in liquid one-tenth-strength NSY medium $\left(0.3 \mathrm{~g} \mathrm{l}^{-1}\right)$ with and without $0.5 \mathrm{~g}$ test substance $\mathrm{l}^{-1}$. Differences in $\mathrm{OD}_{575}$ 
of $<10,10-50$ and $>50 \%$ compared with growth on the medium without the test substance after 10 days of growth were respectively scored as no utilization, weak utilization and good utilization.

Analysis of the phylogenetic position of the strain was performed by means of 16S rRNA gene sequence analysis. Sequences were obtained, aligned and analysed by the neighbour-joining approach as described previously (Hahn et al., 2009). In addition, trees were constructed by using the maximum-likelihood and Bayesian-inference treebuilding methods. For the maximum-likelihood tree calculation and bootstrap analysis, we used the genetic algorithm GARLI (Zwickl, 2006) and a grid computing system (Cummings \& Huskamp, 2005). A Bayesian inference tree was calculated by using the program MrBayes (Ronquist \& Huelsenbeck, 2003), performing one million generations, and subsequently explored by the AWTY system (Nylander et al., 2008). Determination of the $\mathrm{G}+\mathrm{C}$ content of DNA and analyses of major respiratory lipoquinones were both carried out by the Identification Service and Dr B. J. Tindall, DSMZ, Braunschweig, Germany. Fatty acid profiles of strain MWH-C $5^{\mathrm{T}}$ and the type strains of Curvibacter gracilis and Rhodoferax fermentans were characterized by using the MIS Sherlock automatic identification system (MIDI, Inc.) and the Sherlock Aerobic Bacterial Database (TSBA60) as described by Greenblatt et al. (1999). For each strain, biomass for the analysis came from replicated cultures obtained by growing the strains in NSY $\left(3 \mathrm{~g} \mathrm{l}^{-1}\right)$ for 2 days at $21{ }^{\circ} \mathrm{C}$.

The results of the phenotypic and chemotaxonomic investigations are presented in Tables 1 and 2. Strain $\mathrm{MWH}-\mathrm{C}^{\mathrm{T}}$ is an aerobic, chemo-organotrophic, facultatively anaerobic, non-motile bacterium; cells are small, curved rods (Fig. 1). The predominant fatty acids ( $>5 \%$ of total) of the strain were $\mathrm{C}_{16: 1} \omega 7 c / \omega 6 c$ and $\mathrm{C}_{16: 0}$, the sole 3-hydroxy fatty acid detected was $\mathrm{C}_{8: 0} 3-\mathrm{OH}$, the major quinone was ubiquinone Q- 8 and the $\mathrm{G}+\mathrm{C}$ content of the DNA of the strain was $55.5 \mathrm{~mol} \%$.

Phylogenetic analyses with all three tree-building methods consistently revealed the affiliation of strain $\mathrm{MWH}-\mathrm{C}^{\mathrm{T}}$ with the family Comamonadaceae (Fig. 2). The sequence of the strain did not cluster within any previously described genus in any tree generated with the three methods. The phylogenetic relationships reconstructed by using the three algorithms indicated in all three cases a close relationship of the strain with the genera Rhodoferax, Pseudorhodoferax, Curvibacter, Polaromonas, Variovorax, Ramlibacter and Caenimonas. Regarding the phylogenetic relationships of strain $\mathrm{MWH}-\mathrm{C}^{\mathrm{T}}$ to these seven genera, the topologies and branching orders of the three trees were almost identical (not shown). The trees differed only in the position of the type species of the genus Caenimonas, which clustered with the genus Ramlibacter in the maximum-likelihood and Bayesian-inference trees and with the genus Curvibacter in the neighbour-joining tree. Pairwise sequence similarity of the 16S rRNA genes of strain MWH-C5 ${ }^{\mathrm{T}}$ and type strains of the type species of these seven closely related genera was 94.4-96.2\% (mean 95.3\%), which is similar to the range of 93.0-96.5\% (mean 95.4\%) observed for pairwise comparisons among the type species of the seven genera (Supplementary Table S1, available in IJSEM Online).

A family-wide comparison was performed of traits of strain $\mathrm{MWH}-\mathrm{C}^{\mathrm{T}}$ and the type strains of the species of all 30 genera (including Pseudorhodoferax described by Bruland et al., 2009) currently assigned to the family Comamonadaceae. This comparative analysis was limited by the heterogeneity of the datasets available for the different type species, because only a few traits have been described for the overwhelming majority of strains and virtually no test of substrate utilization has been performed for almost all strains. However, comparisons of chemotaxonomic traits, i.e. type of quinone, major fatty acids, major 3-hydroxy fatty acid and G+C content, revealed a unique combination of these traits for strain $\mathrm{MWH}-\mathrm{C} 5^{\mathrm{T}}$ among all genera of the Comamonadaceae (Supplementary Table S2). Strain MWH-C5 ${ }^{\mathrm{T}}$ differs from all but two genera in its DNA $\mathrm{G}+\mathrm{C}$ content of $55.5 \mathrm{~mol} \%$, which is $>3 \mathrm{~mol} \%$ lower than that of the other type strains. Among type strains of the Comamonadaceae, only those of Gisbergeria species (Grabovich et al., 2006) and the type strain of the type species of the genus Polaromonas (Polaromonas vacuolata; Irgens et al., 1996) possess G $+\mathrm{C}$ contents $<59 \mathrm{~mol} \%$. Interestingly, Polaromonas vacuolata differs significantly from the type strains of three other Polaromonas species, which have $\mathrm{G}+\mathrm{C}$ contents of 61.5$63.7 \mathrm{~mol} \%$ (Weon et al., 2008). The G $+\mathrm{C}$ content of the fifth described Polaromonas species has not been reported (Kämpfer et al., 2006). Furthermore, the absence of $\mathrm{C}_{10: 0}$ $3-\mathrm{OH}$ is rare among bacteria of the Comamonadaceae, and all genera that share this trait with strain $\mathrm{MWH}-\mathrm{C5}^{\mathrm{T}}$ possess $\mathrm{G}+\mathrm{C}$ contents $>59 \mathrm{~mol} \%$.

A more detailed comparison with the seven most closely related genera (Fig. 2) revealed several differences from the type species of these genera that are suitable for discrimination of the new taxon from these previously described taxa (Table 3). The $\mathrm{G}+\mathrm{C}$ content is again an important discriminative trait; however, the strain also differs in at least one additional trait from all other type species: for instance, from Caenimonas, Pseudorhodoferax and Variovorax by the absence of $\mathrm{C}_{10: 0} 3-\mathrm{OH}$, from the strictly aerobic Polaromonas by its ability to grow facultatively anaerobically, from Curvibacter type strains by a much lower salinity tolerance, from Ramlibacter by the ability to assimilate glucose and citrate and from Rhodoferax type strains by the ability to utilize $\alpha$-ketoglutarate as a carbon source and the lack of rhodoquinone.

BLAST searches with the 16S rRNA gene sequence of strain $\mathrm{MWH}-\mathrm{C5}^{\mathrm{T}}$ and subsequent phylogenetic analyses revealed that strain $\mathrm{MWH}-\mathrm{C} 5^{\mathrm{T}}$ is closely related to a large number of uncultured strains (Supplementary Fig. S1) detected in cultivation-independent investigations on the diversity of 
Table 1. Phenotypic traits of strain $\mathrm{MWH}-\mathrm{C} 5^{\top}$ and related type strains

Strains: 1, MWH-C5 $5^{\mathrm{T}}$; 2, Curvibacter gracilis CCUG $49445^{\mathrm{T}}$; 3, Rhodoferax fermentans CCUG $45364^{\mathrm{T}}$. The reference strains represent the type strains of the type species of the genera Curvibacter and Rhodoferax. Data were obtained in this study unless indicated. Substrate utilization tests were performed for all three strains under the same conditions. All three strains assimilated acetate, pyruvate, fumarate, succinate, citrate, gluconate and glucose and none of the strains assimilated L-carnitine. All three strains have curved rod-shaped cells and are oxidase- and catalase-positive. -, Negative; +, positive; w, weakly positive; RQ, rhodoquinone; ND, no data available.

\begin{tabular}{|c|c|c|c|}
\hline Characteristic & 1 & 2 & 3 \\
\hline Cell length $(\mu \mathrm{m})$ & $1.0-1.5$ & $1.1-2.8^{a_{\star}}$ & $1.5-3.0^{b}$ \\
\hline Cell width $(\mu \mathrm{m})$ & $0.4-0.5$ & $0.4-0.5^{a}$ & $0.6-0.9^{b}$ \\
\hline Temperature for growth $\left({ }^{\circ} \mathrm{C}\right)$ & $4-34$ & $9-40 \dagger$ & ND \\
\hline Maximum $\mathrm{NaCl}$ concentration $(\% \mathrm{w} / \mathrm{v})$ & 0.5 & $<3^{a}$ & $\mathrm{ND}$ \\
\hline Anaerobic growth & + & $\mathrm{ND}$ & $+^{c}$ \\
\hline \multicolumn{4}{|l|}{ Utilization of: } \\
\hline Ethanol & $\mathrm{W}$ & - & $\mathrm{W}$ \\
\hline Glycerol & - & + & + \\
\hline Glyoxylate & - & $\mathrm{w}$ & - \\
\hline Gycolate & - & + & - \\
\hline D-Glycerate & + & + & $\mathrm{W}$ \\
\hline Oxalate & - & - & $\mathrm{W}$ \\
\hline DL-Lactate & - & + & - \\
\hline Propionate & $\mathrm{W}$ & + & $\mathrm{W}$ \\
\hline DL-Malate & + & + & $\mathrm{W}$ \\
\hline Malonate & - & $\mathrm{w}$ & - \\
\hline$\alpha$-Ketoglutarate & + & + & $\mathrm{W}$ \\
\hline Oxaloacetate & - & + & $\mathrm{w}$ \\
\hline L-Arginine & - & - & + \\
\hline L-Glutamate & - & + & + \\
\hline L-Glutamine & - & + & $\mathrm{W}$ \\
\hline L-Histidine & - & + & - \\
\hline L-Phenylalanine & - & + & - \\
\hline L-Proline & - & + & + \\
\hline L-Serine & - & + & + \\
\hline L-Tryptophan & - & + & $\mathrm{W}$ \\
\hline D-Ribose & $\mathrm{w}$ & w & + \\
\hline L-Sorbose & - & w & - \\
\hline D-Galactose & $\mathrm{w}$ & w & + \\
\hline D-Mannose & + & w & + \\
\hline Sucrose & w & + & $\mathrm{w}$ \\
\hline$N$-Acetylglucosamine & - & $\mathrm{w}$ & + \\
\hline Betaine & - & - & $\mathrm{w}$ \\
\hline Spermidine & - & - & W \\
\hline Quinone type & Q-8 & $\mathrm{Q}-8^{a}$ & $\mathrm{Q}-8, \mathrm{RQ}-8^{c}$ \\
\hline DNA G $+\mathrm{C}$ content $(\mathrm{mol} \%)$ & 55.5 & $66.0^{a}$ & $60^{c}$ \\
\hline
\end{tabular}

${ }^{\star}$ Data taken from: $a$, Ding \& Yokota (2004); b, Madigan et al. (2000); c, Hiraishi et al. (1991). $\dagger$ Data presented by Ding \& Yokota (2004) in the description of the genus Curvibacter.

freshwater bacteria (e.g. Crump \& Hobbie, 2005; Shaw et al., 2008; Zwart et al., 2002). Some of these uncultured bacteria share 16S rRNA gene sequence similarities of $99.9 \%$ with strain $\mathrm{MWH}-\mathrm{C}^{\mathrm{T}}$. The phylogenetic cluster formed by these uncultured organisms was previously designated the 'Rhodoferax sp. BAL47' cluster (Zwart et al., 2002). The large number of sequences affiliated with this cluster, as well as their geographically widespread origins, indicates a significant contribution of bacteria affiliated with this cluster to bacterioplankton in many freshwater lakes and ponds. This is also indicated by an investigation of 15 diverse lakes in northern Europe for the presence of bacteria affiliated with the 'Rhodoferax sp. BAL47' cluster or 14 other clusters that also contain taxa frequently 
Table 2. Whole-cell fatty acid compositions of strain MWH$\mathrm{C}^{\top}$ and related type strains

Strains: 1, MWH-C5 $5^{\mathrm{T}} ; 2$, Curvibacter gracilis CCUG $49445^{\mathrm{T}} ; 3$, Rhodoferax fermentans CCUG $45364^{\mathrm{T}}$. The three strains were cultivated under identical conditions [NSY medium $\left(3 \mathrm{~g} \mathrm{l}^{-1}\right)$ at $21{ }^{\circ} \mathrm{C}$ for 2 days]. The presented data were obtained in this study from replicated cultures. Values are percentages of total fatty acids. ND, Not detected.

\begin{tabular}{|lccc|}
\hline Fatty acid & $\mathbf{1}$ & $\mathbf{2}$ & $\mathbf{3}$ \\
\hline $\mathrm{C}_{8: 0} 3-\mathrm{OH}$ & 2.7 & 3.9 & 5.1 \\
$\mathrm{C}_{9: 0} 3-\mathrm{OH}$ & $\mathrm{ND}$ & 0.1 & $\mathrm{ND}$ \\
$\mathrm{C}_{10: 0} 3-\mathrm{OH}$ & $\mathrm{ND}$ & $\mathrm{ND}$ & 0.2 \\
$\mathrm{C}_{12: 0}$ & 4.5 & $\mathrm{ND}$ & 5.6 \\
$\mathrm{C}_{12: 0} 3-\mathrm{OH}$ & $\mathrm{ND}$ & $\mathrm{ND}$ & $\mathrm{ND}$ \\
$\mathrm{C}_{14: 0}$ & 1.0 & 0.2 & 1.2 \\
$\mathrm{C}_{14: 1} \omega 5 c$ & 0.4 & $\mathrm{ND}$ & 0.3 \\
$\mathrm{C}_{15: 0}$ & $\mathrm{ND}$ & 2.0 & $\mathrm{ND}$ \\
$\mathrm{C}_{15: 1} \omega 6 c$ & $\mathrm{ND}$ & 0.1 & 0.1 \\
$\mathrm{C}_{15: 1} \omega 8 c$ & $\mathrm{ND}$ & 0.2 & $\mathrm{ND}$ \\
$\mathrm{C}_{16: 0}$ & 14.0 & 46.3 & 15.2 \\
$\mathrm{C}_{16: 1} \omega 5 c$ & 0.2 & 0.3 & 0.8 \\
$\mathrm{C}_{16: 1} \omega 7 c / \omega 6 c$ & 76.7 & 44.1 & 49.2 \\
$\mathrm{C}_{17: 0}$ & $\mathrm{ND}$ & 0.4 & $\mathrm{ND}$ \\
$\mathrm{C}_{17: 0} \mathrm{cyclo}$ & $\mathrm{ND}$ & $\mathrm{ND}$ & $\mathrm{ND}$ \\
$\mathrm{C}_{17: 1} \omega 6 c$ & $\mathrm{ND}$ & 0.6 & 0.6 \\
$\mathrm{C}_{17: 1} \omega 8 c$ & $\mathrm{ND}$ & 0.2 & $\mathrm{ND}$ \\
$\mathrm{C}_{18: 0}$ & 0.3 & $\mathrm{ND}$ & $\mathrm{ND}$ \\
$\mathrm{C}_{18: 1} \omega 7 c 11-\mathrm{methyl}$ & 0.3 & 0.2 & 0.7 \\
$\mathrm{C}_{18: 1} \omega 7 c / \omega 6 c$ & 1.8 & 1.3 & 20.7 \\
$\mathrm{C}_{18: 1} \omega 9 c$ & 0.2 & $\mathrm{ND}$ & $\mathrm{ND}$ \\
$\mathrm{C}_{19: 1} \omega 6 c / \mathrm{C}_{19: 0}$ cyclo & $\mathrm{ND}$ & 0.1 & $\mathrm{ND}$ \\
& & & \\
\hline
\end{tabular}

detected in freshwater habitats by a cultivation-independent method (Lindström et al., 2005; Zwart et al., 2003). The 'Rhodoferax sp. BAL47' cluster and an actinobacterial cluster were the only clusters detected in all 15 investigated habitats. A prominent and well-investigated subgroup of the 'Rhodoferax sp. BAL47' cluster is the so-called R-BT065 group (Šimek et al., 2001, 2005), which can be detected by a specific fluorescent in situ hybridization (FISH) probe. Investigations of several freshwater ponds and lakes by using this FISH probe revealed that the targeted cells possess a planktonic lifestyle and that this taxon typically comprises $5-30 \%$ (maximum $\sim 50 \%$ ) of the total bacterioplankton cells in non-acidic stagnant freshwater habitats (Kasalický et al., 2010; Šimek et al., 2001, 2005, 2010a). The origin of strain $\mathrm{MWH}-\mathrm{C} 5^{\mathrm{T}}$ from the pelagic zone of a freshwater lake, as well as the close phylogenetic relationship with strains inhabiting the water column of freshwater systems, indicates that this strain shares a planktonic lifestyle with R-BT065 bacteria and other members of the 'Rhodoferax sp. BAL47' cluster.

On the basis of the reconstructed phylogenetic position of strain MWH-C5 ${ }^{\mathrm{T}}$ (Fig. 2), the phylogenetic distances from type species of the closest related genera (Supplementary

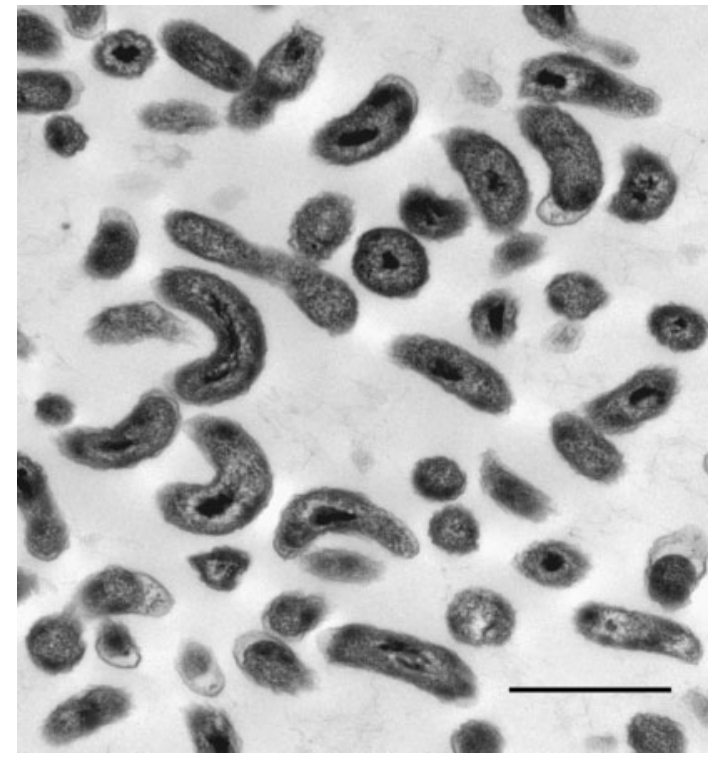

Fig. 1. Electron microscope image illustrating cell morphology and size of strain $\mathrm{MWH}-\mathrm{C} 5^{\top}$. Cells of a liquid culture were concentrated by centrifugation and fixed with $2.5 \%$ glutaraldehyde, post-fixed with $\mathrm{OsO}_{4}$ and embedded with Spurr resin. Ultrathin sections were counterstained with uranyl acetate and lead citrate. The image was obtained by transmission electron microscopy at $\times 20000$ magnification.

Table S1) and the phenotypic and chemotaxonomic differences between the strain and type species of related genera (Table 3 and Supplementary Table S2), we propose to establish the new genus and species Limnohabitans curvus gen. nov., sp. nov. to accommodate strain MWH$\mathrm{C}^{\mathrm{T}}$. The genus Limnohabitans is a diverse taxon consisting of at least four taxonomically and ecologically wellseparated species (Hahn et al., 2010; Kasalický et al., 2010; Šimek et al., 2010b).

\section{Description of Limnohabitans gen. nov.}

Limnohabitans (Lim.no.ha'bi.tans. Gr. n. limne lake; L. part. adj. habitans inhabiting; N.L. part. adj. used as a masc. n. Limnohabitans lake dweller, referring to the type of ecosystem from which the type species was first isolated).

Aerobic, facultatively anaerobic, chemo-organotrophic, oxidase- and catalase-positive bacteria. Cells are nonpigmented, non-motile, curved rods. Not halotolerant; do not grow at $\mathrm{NaCl}$ concentrations $>0.5 \%$. Mesophilic. Major fatty acids (constituting $>5 \%$ of total fatty acids) are $\mathrm{C}_{16: 0}$ and $\mathrm{C}_{16: 1} \omega 0 / \omega 6 c$. The major quinone is ubiquinone Q-8. The only cultured strain was isolated from the water column of freshwater habitats. The genus is affiliated to the class Betaproteobacteria and to the family Comamonadaceae. The type species is Limnohabitans curvus. 


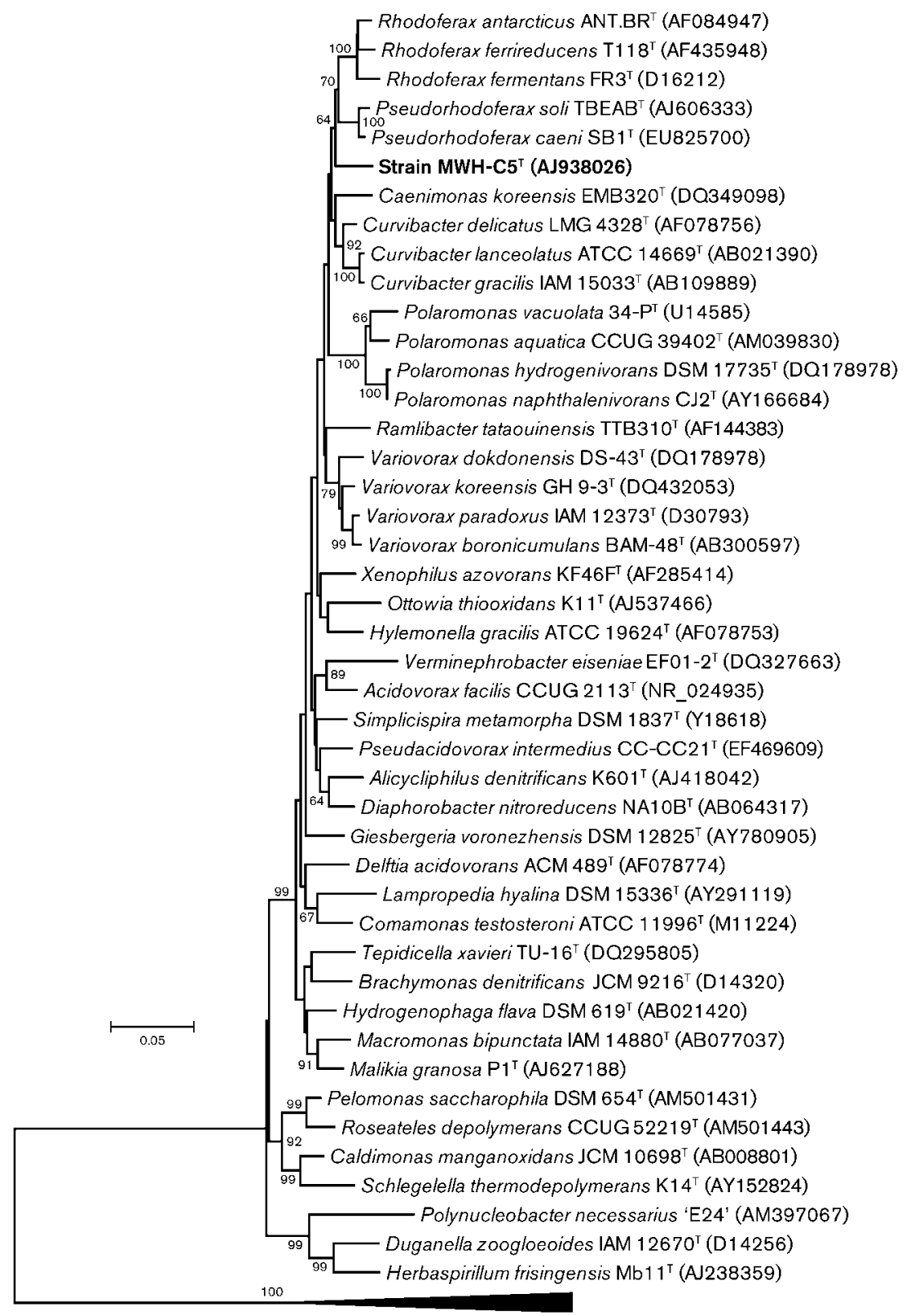

Fig. 2. Neighbour-joining tree (Kimura-2 correction) based on almost-complete $16 \mathrm{~S}$ rRNA gene sequences showing the position of strain $\mathrm{MWH}-\mathrm{C} 55^{\top}$. The tree includes sequences of the type species of almost all genera currently affiliated with the family Comamonadaceae. Only Caenibacterium thermophilum, which was proposed by Lütke-Eversloh et al. (2004) to be a later heterotypic synonym of Schlegelella thermodepolymerans (the type species of the genus Schlegelella), is not shown. Members of the genera Polynucleobacter, Duganella and Herbaspirillum represent reference taxa not affiliated with the family Comamonadaceae. Bootstrap values $\geqslant 60 \%$ (from 1000 iterations) are depicted. The tree was rooted by using archaeal sequences (not shown). Bar, 5 substitutions per 100 nucleotide positions.

\section{Description of Limnohabitans curvus sp. nov.}

Limnohabitans curvus (cur'vus. L. masc. adj. curvus curved or crooked).

Displays the following properties in addition to those described for the genus. Cells are 1.0-1.5 $\mu \mathrm{m}$ long and 0.4-
$0.5 \mu \mathrm{m}$ wide. Colonies grown on NSY agar are unpigmented, circular and convex with smooth surfaces. Growth occurs at $4-34{ }^{\circ} \mathrm{C}$ and with $0-0.5 \%(\mathrm{w} / \mathrm{v}) \mathrm{NaCl}$. Assimilates acetate, glycerate, $\alpha$-ketoglutarate, pyruvate, fumarate, citrate, malate, succinate, gluconate, glucose and mannose. Weak assimilation of several substances is observed (Table 1). 
Table 3. Phenotypic and chemotaxonomic characteristics that differentiate strain $\mathrm{MWH}-\mathrm{C} 5^{\top}$ from related genera

The closest related genera were determined from the phylogenetic reconstruction presented in Fig. 2. Data for reference genera were obtained as follows: Caenimonas (Ryu et al., 2008); Curvibacter (Ding \& Yokota, 2004; this study); Polaromonas (Kämpfer et al., 2006; Sizova \& Panikov, 2007; Jeon et al., 2004; Irgens et al., 1996); Pseudorhodoferax (Bruland et al., 2009); Rhodoferax (Madigan et al., 2000; Hiraishi et al., 1991; Finneran et al., 2003; this study); Variovorax (Yoon et al., 2006; Kim et al., 2006; Miwa et al., 2008); Ramlibacter (Heulin et al., 2003; Ryu et al., 2008). +, Positive; - , negative; NA, no data available; d, variable; w, weak; SF3, summed feature $3\left(\mathrm{C}_{16: 1} \omega 7 c\right.$ and/or iso- $\left.\mathrm{C}_{15: 0} 2-\mathrm{OH}\right)$.

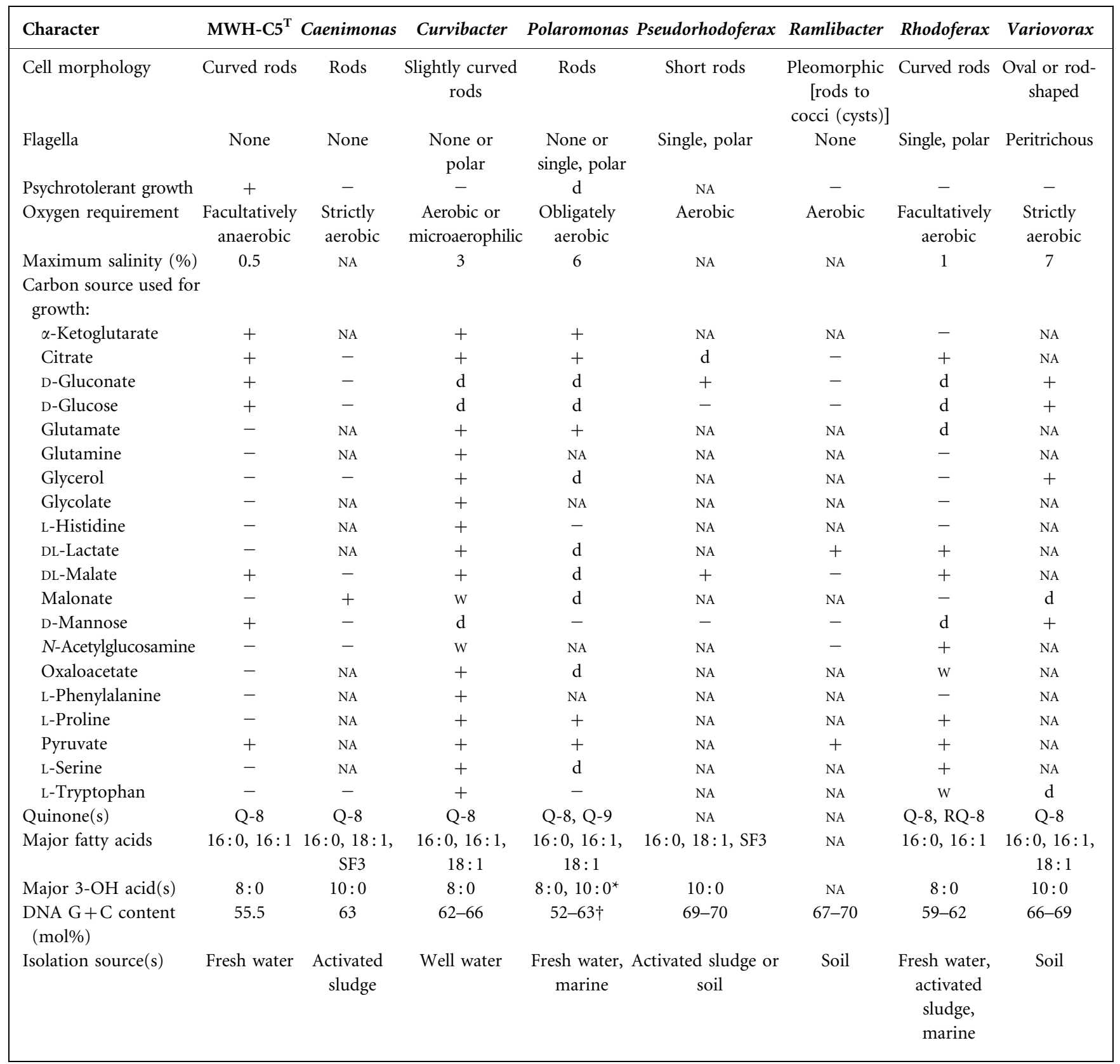

${ }^{*}$ Only Polaromonas hydrogenivorans DSM $17735^{\mathrm{T}}$ and Polaromonas naphthalenivorans $\mathrm{CJ} 2^{\mathrm{T}}$ contain $\mathrm{C}_{10: 0} 3$-OH as the major hydroxylated fatty acid (Jeon et al., 2004; Sizova \& Panikov, 2007).

$\dagger$ Only the type strain of Polaromonas vacuolata has a G + C content of $52 \mathrm{~mol} \%$; the other type strains of Polaromonas species for which data are available have $\mathrm{G}+\mathrm{C}$ contents of $62-64 \mathrm{~mol} \%$.

No assimilation of glycerol, glyoxylate, glycolate, oxalate, lactate, malonate, oxaloacetate, arginine, glutamate, glutamine, histidine, phenylalanine, proline, serine, tryptophan, sorbose, $N$-acetylglucosamine, betaine, spermidine or carnitine. The DNA $\mathrm{G}+\mathrm{C}$ content of the type strain is $55.5 \mathrm{~mol} \%$. 
The type strain is $\mathrm{MWH}-\mathrm{C} 5^{\mathrm{T}}\left(=\mathrm{DSM} 21645^{\mathrm{T}}=\mathrm{CCUG}\right.$ $\left.56720^{\mathrm{T}}\right)$, isolated from Lake Mondsee, Austria.

\section{Acknowledgements}

D. Elhottová and J. Petrásek are acknowledged for determination of fatty acid profiles supported by the project ASCR - ISB no. AV0Z 60660521, and P. Masarova and L. Bucinska are acknowledged for performing electron microscopy. P. Schumann is acknowledged for determination of $\mathrm{G}+\mathrm{C}$ contents and B. J. Tindall is acknowledged for quinone analyses. This study was supported by the CzechAustrian KONTAKT project MEB 060702/CZ 05/2007 (granted to K. S. and M.W.H.), by the Austrian Science Fund (FWF) project P19853 (to M.W.H.), by the Grant Agency of the Czech Republic under research grant 206/08/0015 (to K. S. .) and by the institutional project of the ASCR no. AV0Z 60170517. The authors also benefited from participation in ALTERnet (A Long-Term Biodiversity, Ecosystem and Awareness Research Network), an EU Network of Excellence (GOCE-CT-2003-505298).

\section{References}

Bruland, N., Bathe, S., Willems, A. \& Steinbüchel, A. (2009). Pseudorhodoferax soli gen. nov., sp. nov. and Pseudorhodoferax caeni sp. nov., two members of the class Betaproteobacteria belonging to the family Comamonadaceae. Int J Syst Evol Microbiol 59, 27022707.

Crump, B. C. \& Hobbie, J. E. (2005). Synchrony and seasonality in bacterioplankton communities of two temperate rivers. Limnol Oceanogr 50, 1718-1729.

Crump, B. C., Armbrust, E. V. \& Baross, J. A. (1999). Phylogenetic analysis of particle-attached and free-living bacterial communities in the Columbia River, its estuary, and the adjacent coastal ocean. Appl Environ Microbiol 65, 3192-3204.

Cummings, M. P. \& Huskamp, J. C. (2005). Grid computing. Educause Rev 40, 116-117.

Ding, L. \& Yokota, A. (2004). Proposals of Curvibacter gracilis gen. nov., sp. nov. and Herbaspirillum putei sp. nov. for bacterial strains isolated from well water and reclassification of [Pseudomonas] huttiensis, [Pseudomonas] lanceolata, [Aquaspirillum] delicatum and [Aquaspirillum] autotrophicum as Herbaspirillum huttiense comb. nov., Curvibacter lanceolatus comb. nov., Curvibacter delicatus comb. nov. and Herbaspirillum autotrophicum comb. nov. Int J Syst Evol Microbiol 54, 2223-2230.

Eiler, A. \& Bertilsson, S. (2004). Composition of freshwater bacterial communities associated with cyanobacterial blooms in four Swedish lakes. Environ Microbiol 6, 1228-1243.

Finneran, K. T., Johnsen, C. V. \& Lovley, D. R. (2003). Rhodoferax ferrireducens sp. nov., a psychrotolerant, facultatively anaerobic bacterium that oxidizes acetate with the reduction of $\mathrm{Fe}(\mathrm{III})$. Int $J$ Syst Evol Microbiol 53, 669-673.

Grabovich, M., Gavrish, E., Kuever, J., Lysenko, A. M., Podkopaeva, D. \& Dubinina, G. (2006). Proposal of Giesbergeria voronezhensis gen. nov., sp. nov. and G. kuznetsovii sp. nov. and reclassification of [Aquaspirillum] anulus, [A.] sinuosum and [A.] giesbergeri as Giesbergeria anulus comb. nov., G. sinuosa comb. nov. and G. giesbergeri comb. nov., and [Aquaspirillum] metamorphum and [A.] psychrophilum as Simplicispira metamorpha gen. nov., comb. nov. and S. psychrophila comb. nov. Int J Syst Evol Microbiol 56, 569-576.

Greenblatt, C. L., Davis, A., Clement, B. G., Kitts, C. L., Cox, T. \& Cano, R. J. (1999). Diversity of microorganisms isolated from amber. Microb Ecol 38, 58-68.
Hahn, M. W. (2006). The microbial diversity of inland waters. Curr Opin Biotechnol 17, 256-261.

Hahn, M. W., Stadler, P., Wu, Q. L. \& Pöckl, M. (2004). The filtrationacclimatization method for isolation of an important fraction of the not readily cultivable bacteria. J Microbiol Methods 57, 379-390.

Hahn, M. W., Pöckl, M. \& Wu, Q. L. (2005). Low intraspecific diversity in a Polynucleobacter subcluster population numerically dominating bacterioplankton of a freshwater pond. Appl Environ Microbiol 71, 4539-4547.

Hahn, M. W., Lang, E., Brandt, U., Wu, Q. L. \& Scheuerl, T. (2009). Emended description of the genus Polynucleobacter and the species Polynucleobacter necessarius and proposal of two subspecies, $P$. necessarius subsp. necessarius subsp. nov. and P. necessarius subsp. asymbioticus subsp. nov. Int J Syst Evol Microbiol 59, 2002-2009.

Hahn, M. W., Kasalický, V., Jezbera, J., Brandt, U. \& Šimek, K. (2010). Limnohabitans australis sp. nov., isolated from a freshwater pond, and emended description of the genus Limnohabitans. Int J Syst Evol Microbiol (in press). doi:10.1099/ijs.0.022384-0

Heulin, T., Barakat, M., Christen, R., Lesourd, M., Sutra, L., De Luca, G. \& Achouak, W. (2003). Ramlibacter tataouinensis gen. nov., sp. nov., and Ramlibacter henchirensis sp. nov., cyst-producing bacteria isolated from subdesert soil in Tunisia. Int J Syst Evol Microbiol 53, 589594.

Hiraishi, A., Hoshino, Y. \& Satoh, T. (1991). Rhodoferax fermentans gen. nov., sp. nov., a phototrophic purple nonsulfur bacterium previously referred to as the "Rhodocyclus gelatinosus-like" group. Arch Microbiol 155, 330-336.

Irgens, R. L., Gosink, J. J. \& Staley, J. T. (1996). Polaromonas vacuolata gen. nov., sp. nov., a psychrophilic, marine, gas vacuolate bacterium from Antarctica. Int J Syst Bacteriol 46, 822-826.

Jeon, C. O., Park, W., Ghiorse, W. C. \& Madsen, E. L. (2004). Polaromonas naphthalenivorans sp. nov., a naphthalene-degrading bacterium from naphthalene-contaminated sediment. Int J Syst Evol Microbiol 54, 93-97.

Kämpfer, P., Busse, H.-J. \& Falsen, E. (2006). Polaromonas aquatica sp. nov., isolated from tap water. Int J Syst Evol Microbiol 56, 605-608.

Kasalický, V., Jezbera, J., Simek, K. \& Hahn, M. W. (2010). Limnohabitans planktonicus sp. nov., and Limnohabitans parvus sp. nov., planktonic betaproteobacteria isolated from a freshwater reservoir, and emended description of the genus Limnohabitans. Int $J$ Syst Evol Microbiol (in press). doi:10.1099/ijs.0.018952-0

Kim, B.-Y., Weon, H.-Y., Yoo, S.-H., Lee, S.-Y., Kwon, S.-W., Go, S.-J. \& Stackebrandt, E. (2006). Variovorax soli sp. nov., isolated from greenhouse soil. Int J Syst Evol Microbiol 56, 2899-2901.

Lindström, E. S., Kamst-Van Agterveld, M. P. \& Zwart, G. (2005). Distribution of typical freshwater bacterial groups is associated with $\mathrm{pH}$, temperature, and lake water retention time. Appl Environ Microbiol 71, 8201-8206.

Lütke-Eversloh, T., Elbanna, K., Cnockaert, M. C., Mergaert, J., Swings, J., Manaia, C. M. \& Steinbüchel, A. (2004). Caenibacterium thermophilum is a later synonym of Schlegelella thermodepolymerans. Int J Syst Evol Microbiol 54, 1933-1935.

Madigan, M. T., Jung, D. O., Woese, C. R. \& Achenbach, L. A. (2000). Rhodoferax antarcticus sp. nov., a moderately psychrophilic purple nonsulfur bacterium isolated from an Antarctic microbial mat. Arch Microbiol 173, 269-277.

Miwa, H., Ahmed, I., Yoon, J., Yokota, A. \& Fujiwara, T. (2008). Variovorax boronicumulans sp. nov., a boron-accumulating bacterium isolated from soil. Int J Syst Evol Microbiol 58, 286-289.

Nylander, J. A., Wilgenbusch, J., Warren, D. L. \& Swofford, D. L. (2008). AWTY (are we there yet?): a system for graphical exploration 
of MCMC convergence in Bayesian phylogenetics. Bioinformatics 24, 581-583.

Ronquist, F. \& Huelsenbeck, J. P. (2003). MrBayes 3: Bayesian phylogenetic inference under mixed models. Bioinformatics 19, 1572-1574.

Ryu, S. H., Lee, D. S., Park, M., Wang, Q., Jang, H. H., Park, W. \& Jeon, C. O. (2008). Caenimonas koreensis gen. nov., sp. nov., isolated from activated sludge. Int J Syst Evol Microbiol 58, 1064-1068.

Shaw, A. K., Halpern, A. L., Beeson, K., Tran, B., Venter, J. C. \& Martiny, J. B. (2008). It's all relative: ranking the diversity of aquatic bacterial communities. Environ Microbiol 10, 2200-2210.

Šimek, K., Pernthaler, J., Weinbauer, M. G., Horňák, K., Dolan, J. R., Nedoma, J., Mašín, M. \& Amann, R. (2001). Changes in bacterial community composition, dynamics and viral mortality rates associated with enhanced flagellate grazing in a meso-eutrophic reservoir. Appl Environ Microbiol 67, 2723-2733.

Šimek, K., Horňák, K., Jezbera, J., Mašín, M., Nedoma, J., Gasol, J. M. \& Schauer, M. (2005). Influence of top-down and bottom-up manipulations on the R-BT065 subcluster of $\beta$-proteobacteria, an abundant group in bacterioplankton of a freshwater reservoir. Appl Environ Microbiol 71, 2381-2390.

Šimek, K., Kasalicky, V., Jezbera, J., Jezberová, J., Hejzlar, J. \& Hahn, M. W. (2010a). Broad habitat range of the phylogenetically narrow R-BT065 cluster, representing a core group of the betaproteobacterial genus Limnohabitans. Appl Environ Microbiol 76, 631-639.
Šimek, K., Kasalicky, V., Hornák, K., Hahn, M. W. \& Weinbauer, M. G. (2010b). Assessing niche separation among coexisting Limnohabitans strains through interactions with a competitor, viruses, and a bacterivore. Appl Environ Microbiol 76, 1406-1416.

Sizova, M. \& Panikov, N. (2007). Polaromonas hydrogenivorans sp. nov., a psychrotolerant hydrogen-oxidizing bacterium from Alaskan soil. Int J Syst Evol Microbiol 57, 616-619.

Weon, H. Y., Yoo, S. H., Hong, S. B., Kwon, S. W., Stackebrandt, E., Go, S. J. \& Koo, B. S. (2008). Polaromonas jejuensis sp. nov., isolated from soil in Korea. Int J Syst Evol Microbiol 58, 1525-1528.

Yoon, J.-H., Kang, S.-J. \& Oh, T.-K. (2006). Variovorax dokdonensis sp. nov., isolated from soil. Int J Syst Evol Microbiol 56, 811-814.

Zwart, G., Crump, B. C., Kamst-van Agterveld, M. P., Hagen, F. \& Han, S. K. (2002). Typical freshwater bacteria: an analysis of available $16 \mathrm{~S}$ rRNA gene sequences from plankton of lakes and rivers. Aquat Microb Ecol 28, 141-155.

Zwart, G., van Hannen, E. J., Kamst-van Agterveld, M. P., Van der Gucht, K., Lindström, E. S., Van Wichelen, J., Lauridsen, T., Crump, B. C., Han, S.-K. \& Declerck, S. (2003). Rapid screening for freshwater bacterial groups by using reverse line blot hybridization. Appl Environ Microbiol 69, 5875-5883.

Zwickl, D. J. (2006). Genetic algorithm approaches for the phylogenetic analysis of large biological sequence datasets under the maximum likelihood criterion. PhD thesis, University of Texas at Austin, Austin, TX, USA. 